\title{
PROF. D. J. DU PLESSIS SOOS SY STUDENTE HOM KEN.
}

Ek wil nie by die prehistorie begin nie toe elke dosent nog vir 'n handvol wetenskappe verantwoordelik was. Ek wil maar begin toe die mooi jong man met die pragtige rooi wange nog swaar gedra het aan sy pas verwerfde doktorsgraad in Organiese Skeikunde en toe die P.U.K. al kon spog met 'n deeglik toegeruste (in teëstelling met die ou stal van voorheen!) lesingkamer en laboratorium, een van die tipiese sinktempels uit die worsteltydperk. Met tipiese eerstejaarswysheid het ons gevra waarom 'n man met 'n doktorsgraad sy tyd in hierdie kasarm van 'n laboratorium moet kom verspil. Ons antwoord het van dieselfde wysheid getuig: hy kon niks beters kry nie, dus moes ons maar met hom tevrede wees. Hierdie wysheid het veral ontstaan na aanleiding van die feit dat ons behoorlik ontnugter is na ons eerste kennismaking met die lesingkamer: ons het gehoop ons sal nie verplig word om hard te werk nie. En dit het van die intrapslag vir ons duidelik geword. Prof. du Plessis se „onpopulariteit" het daarin gelê dat hy sy pond vleis geëis het, van die begin af. As mens dit eers besef het, het hy vir jou 'n ander aansien vertoon, al was dit dan meestal op 'n laat uur, met 'n gevaarlike agterstand in die werk. Dan het jy hom leer waardeer as 'n simpatieke leier wat jou probleme kon hanteer.

Prof. du Plessis was voortdurend 'n opvoedkundige by uitstek. Ek kan my nie herinner dat ons hom ooit onvoorbereid betrap het nie (behalwe toe hy huis gebou en op trou gestaan het, maar dit het hom nie in ons oë gediskwalifiseer nie). Daar was altyd sisteem in sy doseerwerk, daar was altyd 'n frisheid in die benadering, want hy het geen metode kans gegee om by hom oud te word en vas te groei nie: hy het altyd weer met iets nuuts en oorspronkliks, meestal rewoiusionêrs na vore gekom. $\mathrm{Hy}$ het altyd geëksperimenteer, want hy wou die studente skeikundiges maak en nie bloot van 'n ,pedigree" voorsien nie. Insig in die grondbeginsels en metodes van die vak was vir hom die sleutel tot sukses daarin.

Van een ding kan prof. du Plessis nooit beskuldig word nie nl. dat hy ons nie geleer het om spaarsaam te werk met apparaat en chemikalieë nie. Hy kon met min klaarkom en kon veel daaruit haal. Dit het ons nie net in die laboratorium besef nie maar ons het dit ook gedemonstreer gesien in sy woonhuis in Reitzstraat en veral in die verlengende motorhuis.

Ek het prof. du Plessis in al die jare nooit ledig gesien nie, of beter gestel, ek het nooit gesien dat hy die indruk van ledigheid of verveeldheid geskep het nie. Mens wonder of hy ooit moeg geword het. Ek glo nie daar is dosente wat huiswerk en toetse gereëlder en vinniger terugbesorg het as hy nie. En snaaks, ek het nooit gehoor dat hy daarvan beskuldig word dat hy die werk ,wetenskaplik" gelees het nie; mens het geweet dis nagesien. Hy was egter een van die suinigste mense wat punte betref - een foutjie in ' $n$ hele antwoord en jy „blaas af". 
Ek het oor prof. du Plessis gepraat hoofsaaklik as dosent, want dit was hy by uitstek. Daarom, en ook omdat hy man alleen die hele vak moes behartig, teoreties sowel as prakties, en daarby nog moes sorg om modern te bly in sy kennis van 'n vak wat met reusespronge feitlik oornag ontwikkel het, daarom kon hy nie soveel aandag aan navorsing wy as wat hy graag wou doen nie. Tog staan hy hoog aangeskrewe by nasionale wetenskaplike verenigings, waarin hy ook 'n leidende rol geneem het. $\mathrm{Hy}$ is altyd met iets nuuts besig, iets waaraan 'n ander nie maklik dink nie. Soms word hy as eksentriek bestempel, maar sy planne werp meestal vrugte af. Daarvan is die departemente Huishoudkunde en Farmasie sprekende voorbeelde.

Ek was eers sy voorgraadse en nagraadse student, toe die onderwyser van sy kinders (nogal in sy vak!), later was hy my hulppromotor oor 'n skeikundig- opvoedkundige onderwerp, toe my kollega op die personeel van die P.U. Daarby het my seun onder hom deurgeloop as student en as kollega in dieselfde departement. Ons was saam diakens, hy voorsitter en kassier, ons het selfs sake saam gedoen, ek as aandeelhouer en hy as direkteur, ons het mekaar soms ondersteun en soms geopponeer. Ons het mekaar opgewek en kwaad gesien, soms saam gelag en soms saam swaar gelrry. En onder al hierdie omstandighede het ek hom kon respekteer. Hy het nooit geskroom om reguit te praat as dit nodig is nie maar kon ook sy foute erken en probeer goed maak.

Ons dink met aangename herinneringe terug aan sy lewe van diens aan die Universiteit en ons gemeenskap. Ons bede is dat die Here hom en sy huis nog lank tot seën naby sal wees.

B. C. SCHUTTE.

P.U. vir C.H.O. 